University of Nebraska - Lincoln

DigitalCommons@University of Nebraska - Lincoln

Biochemistry -- Faculty Publications

Biochemistry, Department of

December 1997

\title{
Intracellular lipid-binding proteins and their genes
}

David A. Bernlohr

University of Minnesota, St. Paul

Melanie A. Simpson

University of Nebraska - Lincoln, msimpson2@unl.edu

Ann Vogel Hertzel

University of Minnesota, St. Paul

Leonard J. Banaszak

University of Minnesota, St. Paul

Follow this and additional works at: https://digitalcommons.unl.edu/biochemfacpub

Part of the Biochemistry, Biophysics, and Structural Biology Commons

Bernlohr, David A.; Simpson, Melanie A.; Vogel Hertzel, Ann; and Banaszak, Leonard J., "Intracellular lipidbinding proteins and their genes" (1997). Biochemistry -- Faculty Publications. 16.

https://digitalcommons.unl.edu/biochemfacpub/16

This Article is brought to you for free and open access by the Biochemistry, Department of at DigitalCommons@University of Nebraska - Lincoln. It has been accepted for inclusion in Biochemistry -- Faculty Publications by an authorized administrator of DigitalCommons@University of Nebraska - Lincoln. 


\title{
Intracellular lipid-binding proteins and their genes
}

\author{
David A. Bernlohr, ${ }^{1,2}$ Melanie A. Simpson, ${ }^{1}$ \\ Ann Vogel Hertzel, ${ }^{1}$ and Leonard J. Banaszak ${ }^{3}$
}

${ }^{1}$ Department of Biochemistry, College of Biological Sciences

${ }^{2}$ Institute of Human Genetics, Medical School

${ }^{3}$ Department of Biochemistry, Medical School, University of Minnesota, St. Paul, Minnesota 55108-1022

\begin{abstract}
Intracellular lipid-binding proteins are a family of low-molecularweight single-chain polypeptides that form 1:1 complexes with fatty acids, retinoids, or other hydrophobic ligands. These proteins are products of a large multigene family of unlinked loci distributed throughout the genome. Each lipid-binding protein exhibits a distinctive pattern of tissue distribution. Transcriptional control, regulated by a combination of peroxisome proliferator activated receptors and CCAAT/enhancer-binding proteins, allows for a variety of both cell and tissue-specific expression patterns. In some cells, fatty acids increase the expression of the lipid-binding protein genes. Fatty acids, or their metabolites, are activators of the peroxisome proliferator-activated receptor family of transcription factors. Therefore, as the concentration of lipid in the diet increases, the expression of lipid-binding proteins coordinately increases. As revealed by X-ray crystallography, the lipid-binding proteins fold into $\beta$-barrels, forming a large internal water-filled cavity. Fatty acid ligands are bound within the cavity, occupying only about one-third of the accessible volume. The bound fatty acid is stabilized via a combination of enthalpic and entropic forces that govern ligand affinity and selectivity. Cytoplasmic lipid-binding proteins are the intracellular receptors for hydrophobic ligands, delivering them to the appropriate site for use as metabolic fuels and regulatory agents.
\end{abstract}

Keywords: fatty acids, carrier proteins, peroxisome proliferator-activated receptors, dietary fat, gene expression

\section{CONTENTS}

Introduction . . . . . . . . . . . . . . . . . . 278

Fatty Acid-Binding Protein Gene Organization . . . . . . . . . . . . . . . . . 279 
Genomic Organization and Structure . . . . . . . . . . . . . . . 279

Evolutionary Relationships and Species Considerations . . . . . . . . . . 281

Fatty Acid-Binding Protein Gene Expression . . . . . . . . . . . . . . . 281

Transcription Factors Affecting FABP . . . . . . . . . . . . . . . . . . 281

Dietary Control of FABP Expression . . . . . . . . . . . . . . . . . . . . . . . . . . . . . . . . . . . . . . . . .

Regulation of FABP Genes . . . . . . . . . . . . . . . . . . . . . . . . 284

Conserved Elements of the FABP Fold . . . . . . . . . . . . . . . . 287

Functional Analysis of the FABPs _. . . . . . . . . . . . . . . . . . . . . 290

Energetic Considerations . . . . . . . . . . . . . . . . . . . . . 293

Hypotheses Concerning FABP Functions . . . . . . . . . . . . . . . . 295

\section{INTRODUCTION}

Ockner et al's 1972 paper entitled "A binding protein for fatty acids in cytosol of intestinal mucosa, liver, myocardium, and other tissues" (81) is generally credited with providing the impetus for studies of the structure, function, and regulation of the intracellular lipid-binding protein multigene family. Some 25 years later, the number of contributions to the literature has grown to 1500 . The diversity of topics ranges from high-resolution X-ray crystallographic analysis of the fatty acid-binding proteins and the role(s) of weak forces in lipid binding to molecular genetic studies of the linkage between polymorphisms in the intestinal fatty acid-binding protein gene and diabetes. Popular textbooks now contain information concerning intracellular fatty acid-binding proteins in lipid metabolism, and scientific meetings are organized around the topic.

Because dietary fats typically constitute over $30 \%$ of the caloric intake, the metabolic relationships between intracellular fatty acid-binding proteins and the trafficking of nutritionally derived lipids remains an active area of research. The flux of fatty acids into, out of, and between cells is emerging as a key facet of information transfer between cells. Fatty acids function not only as components of membranes or storage depots but also as critical signaling molecules playing fundamental roles in areas such as differentiation, development, and hormone action. Transgenic animals lacking certain fatty acid-binding proteins exhibit altered expression of lipid-regulated genes, suggesting the involvement of lipid-binding proteins in signal transduction (42) These examples point out the close association between nutrient sensing and cytoplasmic carrier proteins of dietary lipids.

As Ockner's paper indicated, a variety of tissue and cell types express intracellular lipid-binding proteins. Analysis of the organization of lipid-binding protein genes indicates an evolutionary relationship among the proteins and points toward extensive gene duplication events as the origin of the many different family members. To date, at least 23 members of the intracellular lipid-binding protein multigene family have been described; some preferentially bind fatty acids or related compounds while others associate with reti- noids and vitamin A derivatives. To avoid overlap with Li \& Norris's discussion of the intracellular retinoid-binding proteins (69), this review focuses on the fatty acid-binding members of the gene family and touches on retinoidbinding proteins and their genes only as they relate to the fatty acid-binding proteins. This review summarizes current knowledge of the structure and genetics of lipid-binding proteins in hopes that it may foster new insights into the functional aspects of these fascinating proteins.

\section{FATTY ACID-BINDING PROTEIN GENE ORGANIZATION}

Genomic Organization and Structure

Somatic cell hybrids and restriction fragment length polymorphisms (RFLP) have been used to determine the chromosome locations of many fatty acid-binding protein (FABP) genes (Table 1; see also 12, 36, 39, 82, 86, 112 , 118). At least in humans and mice, the genes encoding FABPs are dispersed throughout the genome. There appear to be no linkages between any of the genes for fatty acid- and retinoid-binding protein genes.

The gene structure of the FABP family has been conserved amongst all members studied thus far (Figure 1; 33, 45, 78, 87, 114, 118; AV Hertzel, DA Bernlohr, manuscript in preparation). Each gene contains four exons separated by three introns. Although the length of the introns varies, the length of the exons has been maintained such that the positions of the introns within the genes are essentially identical. Furthermore, this conservation of gene structure for the FABPs is also maintained in other members of the lipid-binding protein multigene family. For example, the cellular retinol binding protein and cellular retinoic acid binding protein genes all have four exons and three introns, although the average length of the introns far exceeds that of the FABP genes (69).

Table 1 Chromosomal location of fatty acid binding protein genes

\begin{tabular}{lcl}
\hline \hline Gene $^{\mathrm{a}}$ & Mouse & Human \\
\hline ALBP (aP2) & 3 & \\
LFABP & 6 & $2(\mathrm{p} 12-\mathrm{q} 12)$ \\
IFABP & 3 & $4(\mathrm{q} 28-\mathrm{q} 31)$ \\
HFABP & 4 & $1(\mathrm{pter}-\mathrm{q} 31)$ \\
$\quad$ Heart pseudogene & 10 & \\
$\quad$ Heart related & 8 & 5 \\
ILBP & 11 & $8(\mathrm{q} 21.3-\mathrm{q} 22.1)$ \\
Myelin P2 & &
\end{tabular}

${ }^{a}$ ALBP, Adipocyte (39); LFABP, liver (112); IFABP, intestinal (112); HFABP, heart $(86,118)$; ILBP, ileal $(12,82)$; myelin P2 (36). 


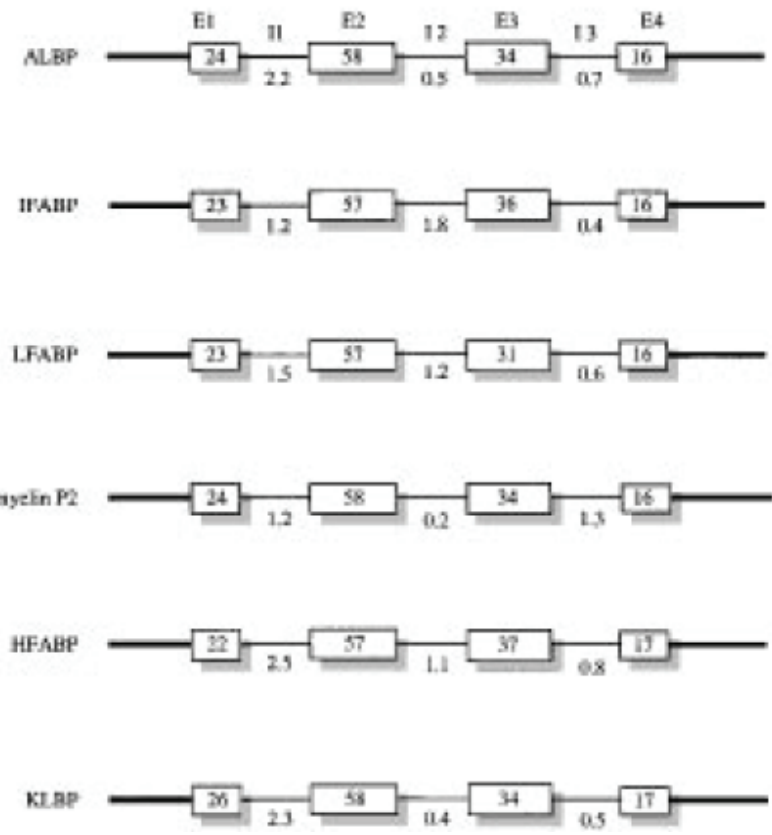

Figure 1 Comparison of the structures of the genes for fatty acid-binding proteins. E, Exon; I, in tron. The numbers in the boxes indicate the number of amino acids encoded within each exon. The bold lines represent the $5^{\prime}$ and $3^{\prime}$ nontranslated portions of exon 1 and exon 4 , respectively, which are of variable lengths. The intron lengths are in kilobase pairs. ALBP, Murine adipocyte LBP $(45,87)$; IFABP, murine intestinal FABP (33); LFABP, rat liver FABP (114); myelin P2, murine myelin P2 (78); HFABP, bovine heart FABP (118); KLBP, murine keratinocyte LBP (AV Hertzel, DA Bernlohr, manuscript in preparation).

Most of the FABP genes exist in a single copy in the genome. Presently, there are two exceptions: heart HFABP and keratinocyte lipid-binding protein (LBP). In humans the heart FABP gene seems to be present in a single copy, whereas the murine heart FABP gene is represented three times, once each on chromosomes 4, 8, and 10 (39). The copy on chromosome 4 contains three introns, similar to the other FABP genes, and is presumably the functional copy (118). The gene on chromosome 10 lacks introns and therefore appears to be a pseudogene. The copy on chromosome 8 may represent a related gene (39). Southern analysis using the murine keratinocyte LBP cDNA revealed multiple bands for each restriction endonuclease used, suggesting the presence of five to six copies of the keratinocyte LBP gene (60). Only one copy contains a third intron, suggesting a single functional keratinocyte LBP gene (AV Hertzel, DA Bernlohr, manuscript in preparation).

\section{Evolutionary Relationships and Species Considerations}

FABPs have been discovered in many organisms, including humans, cows, pigs, mice, rats, rabbits, guinea pigs, fish, chickens, worms, sharks, frogs, and insects $(121,125 \mathrm{a})$. The orthologous FABP genes expressed in any given tissue appear to be conserved throughout the various organisms. For example, the liver FABPs from mice and humans are more closely related to each other than to other mouse and/or human FABPs. One exception is shark liver FABP: It appears to resemble rat heart FABP more than rat liver FABP (72). The presence of so many different but highly related genes probably originates from a series of duplications from a common ancestral gene. A complete analysis of the evolutionary relatedness of proteins in the FABP family has indicated the relative similarity of these proteins and has identified the positions of gene duplications, of which at least 14 appear (101). Only two of these duplications took place after the divergence of invertebrates from vertebrates.

\section{FATTY ACID-BINDING PROTEIN GENE EXPRESSION}

Fatty acid-binding proteins are expressed abundantly (1-5\% of cytosolic protein) in cells involved in active lipid metabolism. Although all cells require fatty acids for membranes, many tissue types such as liver, muscle, and adipose have high flux rates of fatty acids utilized for energy and storage. Members of the FABP family exhibit unique tissue-specific expression patterns and were named according to the tissue in which each was first identified. Some show restricted tissue distribution, whereas others are more widespread. For example, adipocyte LBP (10), intestinal FABP (20), epidermal FABP (105), myelin P2 (77), brain FABP (62), and testis LBP (also known as PERF15; 83) are each expressed in a single tissue. Liver FABP $(35,106,111)$, ileal LBP $(30,97)$, and keratinocyte LBP $(60)$ are expressed in a limited number of tissues. Heart FABP $(85,132)$ exhibits the broadest tissue distribution occurring in heart, skeletal muscle, mammary, lung, brain, kidney, testis, ovary, stomach, and adrenal tissues.

FABP genes are expressed in specific cell types within a tissue(s) as a function of the stage of development or differentiation. For example, intestinal FABP has two gradients of expression within the intestine: a vertical gradient (crypt to villus) and a horizontal gradient (duodenal to colon), with the highest levels of expression in the jejunum and ileum $(33,121)$.

\section{Transcription Factors Affecting FABP Expression}

Peroxisome proliferators are a group of rodent hepatocarcinogens causing pleiotropic effects on cell morphology and metabolism. These compounds, which include plasticizers, herbicides, and the fibrate class of hypolipidemic 
drugs, are considered to be nongenotoxic because they fail to damage DNA directly. Rather, they may function through an increase in reactive oxygen species produced by induction of the $\mathrm{H}_{2} \mathrm{O}_{2}$-generating peroxisomal enzymes of the fatty acid oxidation system. Peroxisome proliferators act via peroxisome proliferator-activated receptors (PPARs), a multigene family that is part of the supergene family of nuclear receptors, such as the thyroid hormone, retinoic acid, and vitamin D3 receptors (103). There are multiple isoforms of PPAR in mice $(\alpha, \gamma$, and $\delta)(133)$ and in Xenopus laevis $(\alpha, \beta$, and $\gamma)(25,46)$. Sequence conservation among PPAR isoforms is highest in the DNA-binding domain, whereas the ligand-binding domain is less well conserved. The different PPARs bind to hormone response elements (peroxisome-proliferator response elements, PPREs) of the DR- 1 class $\left(\mathrm{TG}^{\mathrm{A}} / \mathrm{T} \mathrm{CCT}\right.$ in a direct repeat separated by one nucleotide) or to imperfect versions of this element (103). Binding affinity may be modified by the sequences that flank these elements (84). PPARs are activated by peroxisome proliferators, hypolipidemic drugs, and fatty acid metabolites. In a heterologous system using CV1 (monkey kidney) cells, peroxisome proliferators activate $\operatorname{PPAR} \alpha(57)$. It is thought that $\operatorname{PPAR} \alpha$ is involved in lipid catabolism, whereas PPAR $\gamma$ is involved in lipid anabolism; the function of PPAR $\delta$ is less well characterized (103).

PPARs bind cooperatively to PPREs as a heterodimer with $\mathrm{RXR} \alpha$ (retinoid $X$ receptor), thereby activating gene transcription (59). The ligand for $\mathrm{RXR} \alpha$ is 9-cis retinoic acid. PPARs binds directly to thiazolidinediones (66) and 15-deoxy ${ }^{\Delta 12,14}$-prostaglandin $\mathrm{J}_{2}(27,58)$. PPAR $\alpha$ binds leukotriene $\mathrm{B}_{4}$ with an apparent dissociation constant of $90 \mathrm{nM}$ (23a). Simultaneous exposure to a PPAR activator and 9-cis retinoic acid causes synergistic induction of gene expression (59).

Although less well characterized, other nuclear receptors, such as LXR $\alpha$ (ligand X receptor), also dimerize with PPARs (74). This dimerization inhibits PPAR function by reducing the amount of PPAR/RXR heterodimer. Also, unliganded PPAR receptors may bind DNA and inhibit transcription, perhaps through co-repressors similar to those that repress the retinoic acid receptor and the thyroid hormone receptor $(15,40)$.

Each PPAR isoform exhibits a unique tissue-specific expression pattern as a result of regulation by various hormones and dietary factors (57). In mice and rats, the alpha isoform is expressed in liver, kidney, heart, brain, and gut; gamma is highly restricted to adipose tissue; and delta is expressed ubiquitously. In hepatocytes, steady-state levels of PPAR $\alpha$ mRNA are decreased by insulin and increased by fatty acids and dexamethasone, although no classical hormone response elements appear to be present in the PPAR promoter $(68,109)$. Furthermore, PPAR $\alpha$ is regulated by a diurnal rhythm paralleling that of corticosterone levels (67). Fasting caused an 80\% decrease in PPAR $\gamma 2$ mRNA levels in mouse adipocytes, whereas a high-fat diet increased levels by $50 \%$ (122)

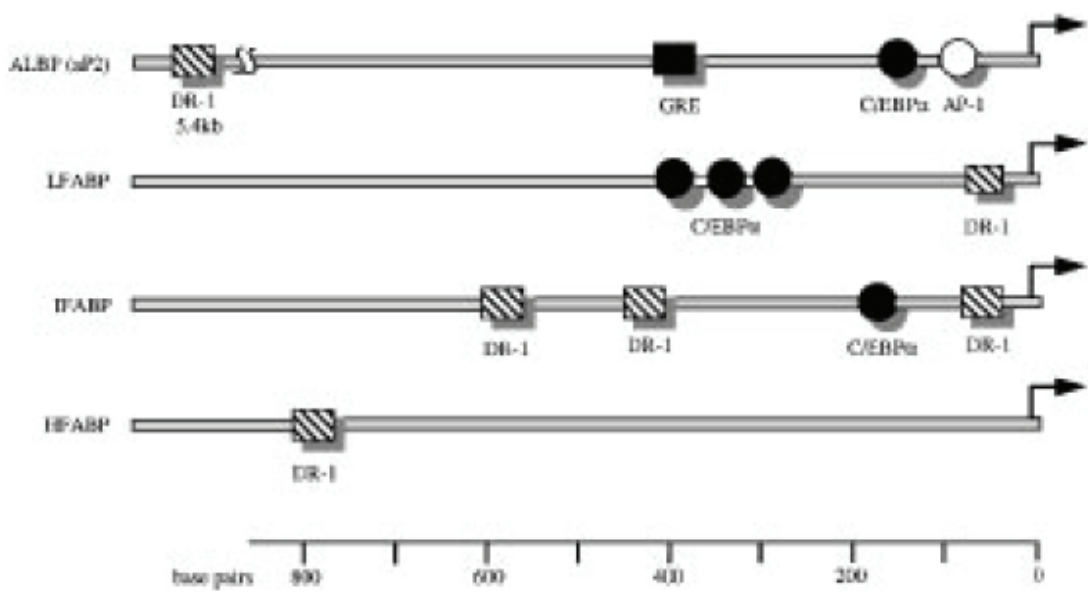

Figure 2 Upstream regulatory elements relative to the start of transcription of murine adipocyte LBP (ALBP; $a P 2$ ), intestinal FABP (IFABP), heart FABP (HFABP), and rat liver FABP (LFABP). The arrows indicate the position of transcription initiation. The ALBP upstream region contains a functional PPAR binding element (DR-1) at $-5.3 \mathrm{~kb}(94,117)$, a glucocorticoid response element (GRE) at -393 to -385 bp (21), a C/EBP $\alpha$ binding site at -149 to -130 (16), and an AP-1 site at -122 to -116 bp (89). Transcription of the LFABP gene is regulated through three C/EBP $\alpha$ binding sites located at -402 to $-385,-356$ to -345 , and -306 to -275 bp $(20,65)$. The DR- 1 site at -75 to -66 bp allows responsiveness to peroxisome proliferators through PPAR $\alpha(47,106)$. IF$\mathrm{ABP}$ is regulated by $\mathrm{C} / \mathrm{EBP} \alpha$ at -188 to -167 bp (20) and contains putative DR-1 elements at -591 to $-579,-430$ to -443 , and -82 to $-69(33,112)$. HFABP's putative DR-1 site is located at -845 bp (118).

In addition to the PPARs, CCAAT/enhancer-binding proteins (C/EBPs; 123) are also involved in the regulation of FABP genes. Many of the FABP genes contain functional C/EBP-binding sites (Figure 2). C/EBPs comprise a family of transcription factors that regulate gene expression through binding to the DNA sequence ATTGCGCAAT, although significant substitutions within this sequence are common (50). These proteins are expressed in tissues known to metabolize lipids and cholesterol and are thought to play a global role in the regulation of intermediary metabolism. During cellular differentiation, C/EBPs can affect the transcriptional activities of several genes, which creates a specialized phenotype leading to the production of a nonproliferating state (120). Several isoforms have been identified based on comparison of their C-terminal DNA-binding domains (125). This region contains the classical basic region/leucine zipper (bZIP) motif, which allows homodimerization as well as heterodimerization with other C/EBP family members. An N-terminal transactivation domain presumably functions through interactions with the transcription machinery. The three isoforms of $\mathrm{C} / \mathrm{EBP}, \alpha, \beta$, and $\delta$, can het- 
erodimerize with one another, bind to similar DNA elements, and transactivate reporter constructs containing $\mathrm{C} / \mathrm{EBP}$ elements (79).

$\mathrm{C} / \mathrm{EBP} \alpha$ (expressed in liver, adipocytes, and proliferating myelomonoblasts) coordinates transcriptional activation of groups of genes (11). Although $\mathrm{C} / \mathrm{EBP} \alpha$ can induce the expression of PPAR $\gamma$ in 3T3-L1 cells, homodimers of $\mathrm{C} / \mathrm{EBP} \beta$ are the primary inducers of PPAR $\gamma$ expression. Both $\mathrm{C} / \mathrm{EBP} \beta$ and $\mathrm{C} / \mathrm{EBP} \delta$ are necessary but not sufficient for transcriptional activation of $\mathrm{C} / \mathrm{EBP} \alpha(127)$.

Insulin reciprocally regulates the transcription of $\mathrm{C} / \mathrm{EBP}$ genes in adipocytes (70). Treatment of 3T3-L1 adipocytes with insulin inhibits repression of transcription of the $\mathrm{C} / \mathrm{EBP} \alpha$ gene. In contrast, insulin treatment rapidly, but transiently, induces the expression of $\mathrm{C} / \mathrm{EBP} \beta$ and $\mathrm{C} / \mathrm{EBP} \delta$. Therefore, an increase in insulin level decreases gene expression from promoters with $\mathrm{C} / \mathrm{EBP}$ binding sites.

\section{Dietary Control of FABP Expression}

The nutritional state of an organism significantly affects FABP expression. For example, following a 2-3 day fast, liver FABP mRNA decreases 30-70\% in the liver (6); conversely, heart FABP is induced twofold in red skeletal muscle (14). On a low-fat diet, levels of liver FABP and intestinal FABP mRNA in the intestine decrease, whereas liver FABP mRNA levels remain constant in the liver (51). Levels of liver FABP in hepatic tissue, normally higher in female than in male mice $(4,7,80,85)$, became similar upon a low-fat diet. In contrast, a high-fat meal results in a nearly twofold increase in liver FABP and intestinal FABP $(4,81)$. In cell culture systems, free fatty acids upregulate liver FABP expression (19). In addition, long-chain fatty acids rapidly induce the expression of adipocyte LBP in a variety of preadipocyte cell lines (24). Therefore, dietary factors, including intake of lipids and fatty acids, affect the abundance of the FABPs.

\section{Regulation of FABP Genes}

ADIPOCYTE LIPID-BINDING PROTEIN (AP2) GENE The adipocyte LBP gene, $a$ P2, is regulated predominantly during the course of adipose conversion as cells differentiate from a fibroblastic precursor cell to a mature adipocyte. Identification of the proteins regulating the increase in expression and the sequence elements to which they bind was facilitated by comparison of the promoter regions of genes induced during adipocyte differentiation (Figure 2). Fat-specific element 2, bound by a c-fos/c-jun complex, activates transcription of $a P 2$ (89). This sequence, also called AP-1, overlaps a negative regulatory element involved in the control of $a P 2$ expression in preadipocytes. Glu- cocorticoids positively regulate $a P 2$ expression, presumably via a response element identified by sequence analysis at position -393 to -385 (21).

$\mathrm{C} / \mathrm{EBP} \alpha$ involvement has been demonstrated in the regulation of many genes that encode proteins of intermediary metabolism. In the promoter region of $a P 2, \mathrm{C} / \mathrm{EBP} \alpha$ binds at -149 to -130 and is a major contributor to the regulation of gene expression in the mature fat cell (16). Adipocyte response element 1 (ARE, located at $-5.3 \mathrm{~kb}$ ) is bound by nuclear factor $1(31)$. Mutation of this sequence significantly reduced the activation of $a P 2$. ARE2 and ARE4 (located at approximately $-5.2 \mathrm{~kb}$ ) are two elements that are bound by ARF2 (adipose regulatory factor 2), and stimulate transcription (32). In cells in culture, mutation of either site decreases $a P 2$ expression by approximately $90 \%$

In cell culture, 168 bases of upstream sequence conferred differentiationdependent expression on linked heterologous promoters. However, neither this nor a larger construct (including $1.7 \mathrm{~kb}$ ) could direct appropriate expression in transgenic mice. Subsequently, an enhancer was discovered, mapping at $-5.4 \mathrm{~kb}$ and $-4.9 \mathrm{~kb}(94)$. The enhancer alone is necessary and sufficient to direct adipocyte-specific expression of a reporter gene in transgenic mice. Within this sequence is a PPRE (DR-1 element) capable of being bound by the heterodimer PPAR $\gamma 2 / \mathrm{RXR} \alpha$ (117). The strict tissue-specific expression of $a P 2$ in adipocytes may be caused by PPAR, which has an expression similar to that of $a P 2$. The involvement of a PPAR is consistent with the observation that thiazolidinediones increase $a P 2$ mRNA levels (34). Fatty acids transcriptionally regulate $a P 2$ in preadipocytes but not in mature fat cells to any extent (24). This observation suggests that in adipocytes, where high levels of adipocyte LBP are present, fatty acids may be relatively ineffective as transcriptional regulators. In summary, many proteins are involved in the regulation of $a P 2$ expression, including $\mathrm{C} / \mathrm{EBP} \alpha$ and $\mathrm{PPAR} \gamma 2$.

INTESTINAL FATTY ACID-BINDING PROTEIN GENE Sequence analysis of the 5' nontranscribed regions of the intestinal FABP genes from mice, rats, and humans indicated three highly conserved domains (112). Intestinal FABP is expressed only in the intestine in a complex pattern of gradients: vertical from crypt to villus and horizontal from duodenum to colon (20). Reporter constructs in transgenic mice demonstrated that the first 227 bases upstream of the start of transcription were capable of directing expression to the small intestine and displaying the appropriate villus-to-crypt gradient (113). However, $1.1 \mathrm{~kb}$ of sequence is necessary to add the proximal-to-distal pattern as well as to acquire normal levels of expression. The sequence -212 to -188 binds a colonderived factor and is located within a region important to the suppression of ileal and colonic expression (20) 
DNase I footprinting experiments using $\mathrm{C} / \mathrm{EBP} \alpha$ resulted in protection of bases -188 to -167 , located within the second of the three conserved domains of the intestinal FABP promoter (20). A construct containing a C/EBP-binding site and one DR-1 element was capable of directing expression of intestinal FABP to the intestine in transgenic animals (20). This DR-1 element is one of three found in the intestinal FABP promoter $(33,97)$. The first element binds a nuclear hormone receptor, ARP-1 (95). Although peroxisome proliferators have only minimal effects on the expression of intestinal FABP, PPAR/RXR heterodimers may bind to these elements and activate transcription. As with other FABPs, C/EBPs and perhaps PPARs appear to be involved in the regulation and tissue-specific expression of intestinal FABP (Figure 2).

LIVER FATTY ACID-BINDING PROTEIN GENE Liver FABP is expressed abundantly in the liver (2-5\% of cytosolic protein), and in a gradient similar to intestinal FABP in the intestine (declining gradient from the jejunum to ileum and from villus tips to crypt cells of villi; 5). Four kilobases of the upstream region of the liver FABP promotor are sufficient to correctly direct expression of a reporter gene in the hepatocyte. Such a construct is expressed in the horizontal, but not the vertical, gradient in the intestine (111). Sequences between -4.0 and $-0.6 \mathrm{~kb}$ are required for suppression of liver FABP expression in the colon and kidney (106).

Both high-fat diets and peroxisome proliferators increase the abundance of liver FABP in the liver and intestine (52). Consistent with these observations, the rat liver FABP gene contains an imperfect PPRE at -76 to $-66 \mathrm{~kb}$ (106). This sequence confers responsiveness to peroxisome proliferators in the presence of PPAR $\alpha$ (47). DNase I footprinting with $\mathrm{C} / \mathrm{EBP} \alpha$ results in the protection of three distinct regions $(20,65)$. Therefore, similar to $a P 2$ and intestinal FABP, the liver FABP promoter contains sequences responsive to both $\mathrm{C} /$ EBPs and PPARs (Figure 2). Unlike other FABPs, liver FABP is able to bind to peroxisome proliferators, which may play a role in regulating the availability of ligands for PPARs (13).

KERATINOCYTE LIPID-BINDING PROTEIN GENE Keratinocyte LBP (formerly called mal-1) was identified as an mRNA that was increased in abundance in murine benign papillomas and malignant squamous-cell carcinoma of skin (60). Expression of keratinocyte LBP mRNA is low in normal skin, tongue, lung, and mammary tissue gland. Elevated levels were detected in SV40-transformed fibroblasts and fibroblasts transformed by other tumor viruses. The rat homo$\log$ is highly expressed in lens epithelial cells (124). Keratinocyte LBP is the first lipid-binding protein to show high levels of induced expression without concomitant cellular differentiation. Many transformed cells contain altered types and quantities of lipids in comparison to wild-type cells. Since fatty ac- ids regulate other FABPs, it is reasonable to hypothesize that keratinocyte LBP may respond similarly, perhaps through a PPAR.

In fat cells, the predominant FABP is adipocyte LBP. However, keratinocyte LBP can be detected at very low levels. Spiegelman and colleagues (42) have developed a line of transgenic mice with a targeted disruption of the $a P 2$ allele. Such animals are fertile, developmentally normal, and phenotypically indistinguishable from heterozygous littermates. As a result of the $a P 2$ disruption, keratinocyte LBP is induced 40-and 14-fold at the levels of mRNA and protein, respectively (N Ribarik Coe, AV Hertzel, DA Bernlohr, manuscript in preparation). Therefore, the lack of $a P 2$ expression is compensated partially by an increase in keratinocyte LBP expression. Consistent with a role of fatty acids in the regulation of these FABPs, the free fatty acid levels are elevated in adipocytes from transgenic mice null for adipocyte LBP. The altered intracellular lipid levels may be indicative of metabolic differences between wild-type and $a P 2$ disruptants. When wild-type animals are fed a high-fat diet ( $40 \%$ fat calories), diet-induced obesity leads to elevated blood glucose levels, insulin resistance, and overexpression of tumor necrosis factor- $\alpha$ (TNF$\alpha$ ). TNF- $\alpha$ indirectly inhibits the tyrosine kinase activity of the insulin receptor, thereby leading to insulin resistance (41). Interestingly, on a high-fat diet, aP2 null mice had normal blood glucose levels, remained insulin sensitive, and lacked TNF- $\alpha$. The observation that elevated dietary fat does not lead to insulin resistance in $a P 2$ null mice suggests a role for adipocyte LBP in insulin action (42).

\section{CONSERVED ELEMENTS OF THE FABP FOLD}

Evolutionary preservation of gene structure between its members is one reason why the fatty acid-binding proteins are classified as a multigene family. Their overall degrees of nucleotide similarity translate to protein primary sequences ranging in identity from 20 to $70 \%$ (Figure 3 ). Despite such wide variability in amino acid conservation, crystal structures obtained for numerous family members have demonstrated a characteristic, superimposable structural arrangement that includes several noteworthy features $(22,99$, 128-131).

Measurements of circular dichroism exhibited by the FABPs gave the first indications of the predominance of $\beta$-sheets in the folded protein. Crystallographic analysis indicates the structure is roughly $70 \% \beta$-sheet conformation. Its topology is relatively simple: ten antiparallel $\beta$-strands each hydrogen-bonded to the adjacent strand to form two $\beta$-sheets that then fold to adopt the shape of a barrel (Figure 4). The two sheets are virtually perpendicular to each other, enabling the first and last $\beta$-strands to hydrogen bond and close the barrel, thus flattening it slightly into what has been described as a $\beta$-clam (96). 


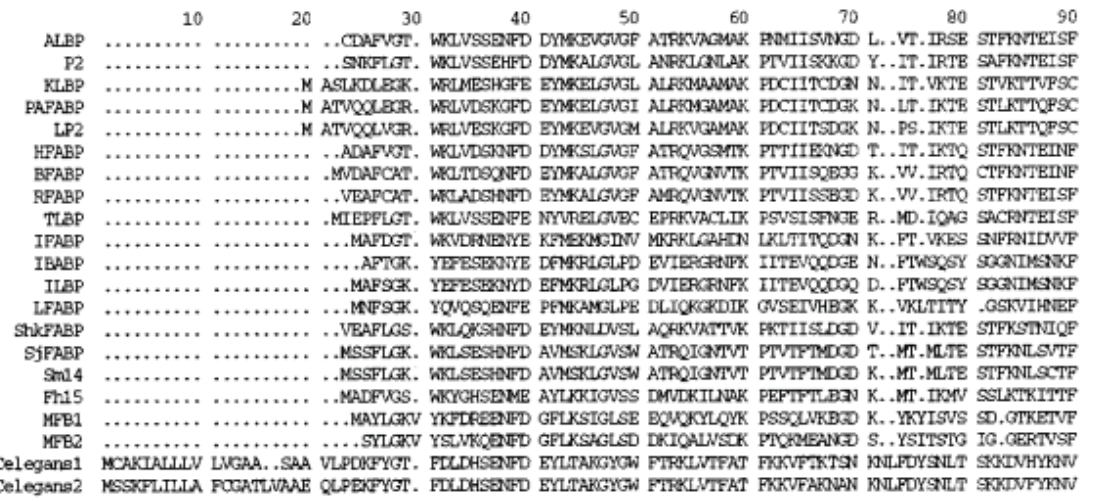

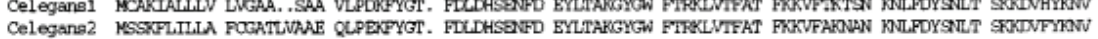

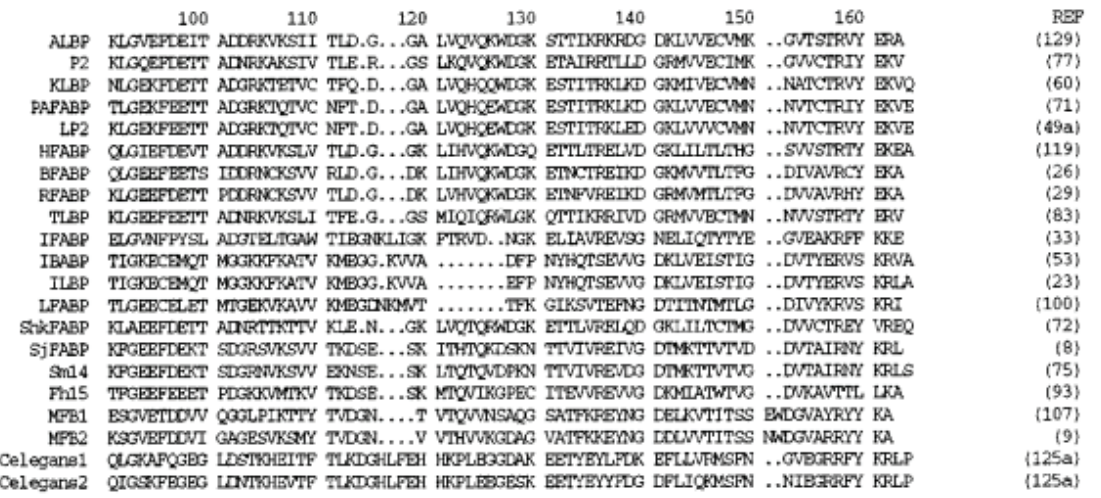

Figure 3 Alignment of the amino acid sequences from representative members of each class of FABP. Dots indicate gaps inserted to optimize alignment. Sequences listed are murine except where indicated below. The 21 sequences are adipocyte LBP (ALBP), myelin P2 (P2), keratinocyte LBP (KLBP), human psoriasis-associated FABP (PAFABP), bovine lens LP2 (LP2), heart FABP (HFABP), brain FABP (BFABP), chick retina (RFABP), rat testis (TLBP), intestinal enterocytes of rat (IFABP, IBABP) or pig (ILBP), liver FABP (LFABP), shark liver FABP(ShkFABP), human blood fluke Schistosoma japonicum FABP (SjFABP), blood fluke Schistosoma mansoni (Sm14), liver fluke Fasciola hepatica (Fh15), and larvae of the moth Manduca sexta (MFB1, MFB2)

The $\beta$-strands are interconnected by short loops, each of which contains only a few amino acids. Between the first and second $\beta$-strands two $\alpha$-helices arranged in a helix-turn-helix motif loop out to cover the mouth of the barrel. The base of the barrel is filled by side-chains. Located within the barrel is the large water-filled ligand-binding cavity of about 400-600 $\AA^{3}$ (approximately 2 -to 3 -fold in excess of the volume required to hold its ligand and 5-10\% of the total protein volume). The cavity wall is lined with amino acid sidechains, roughly $50 \%$ of which are charged or polar residues (3).

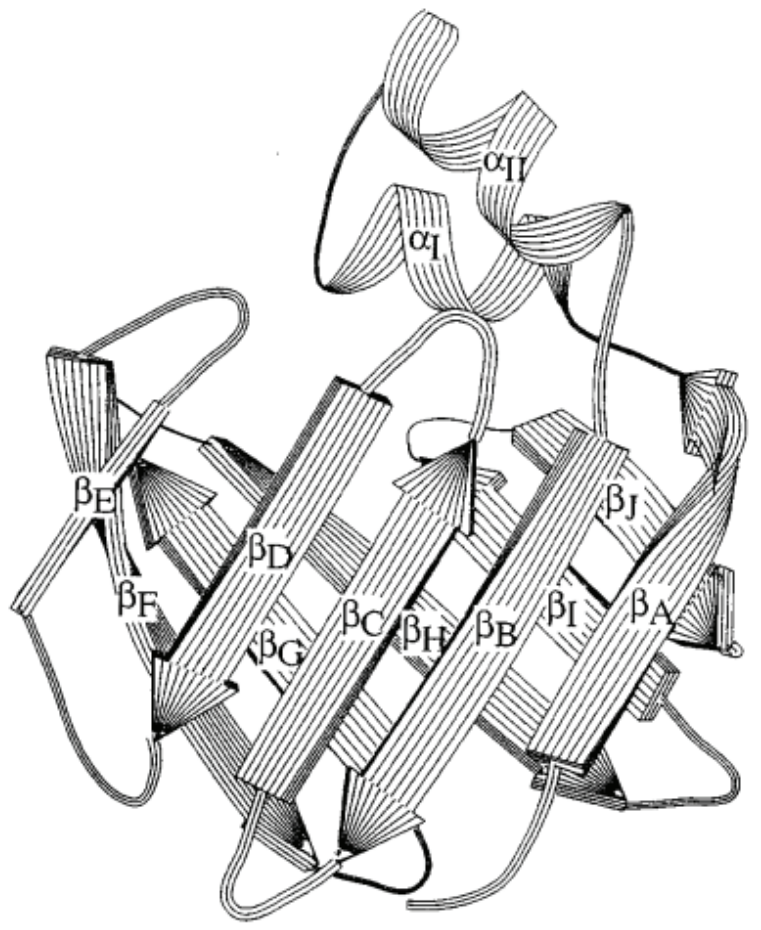

Figure 4 Ribbon diagram of adipocyte LBP apoprotein demonstrating characteristic features of the FABP fold as described in the text. The 10 antiparallel $\beta$-strands are labeled $\beta$ A through $\beta \mathrm{J}$. The $\alpha$-helices are numbered I and II. Reprinted from Reference 128 with permission from the American Chemical Society.

As a result of the flattening of the barrel, one pair of adjacent $\beta$-strands is unable to hydrogen bond. There is a gap between strands $\beta \mathrm{D}$ and $\beta \mathrm{E}$ because of the absence of main-chain hydrogen bonding. In this region the two strands are oriented such that their side-chains fill much of the interstrand space. Crystallographically ordered water molecules fill the remainder (3). This gap may result from a preferred folding pathway as dictated by the hydrophobic backbone. The gap is likely to contribute flexibility to the folded structure, in the sense that it could physically facilitate an opening and closing around larger ligands, and that the same tertiary structure can be formed despite such varying primary structure.

Space-filling models of the FABPs reveal few sites through which the binding cavity is accessible to solvent, and none in the static structure with sufficient dimensions to permit ligand entry. Thus, the region most likely to 
serve as a ligand portal has been deduced by the small amount of exposed area observable in crystal structures, by its greater mobility (higher B-factors), by its differential sensitivity to proteases in the bound vs unbound state (49), and by the effect of mutations to that region upon binding affinities/kinetics $(17,37,56)$. The portal is gated by the helix-turn-helix motif and interstrand loops $\beta \mathrm{C}$-to- $\beta \mathrm{D}$ and $\beta \mathrm{E}$-to- $\beta \mathrm{F}$. Additional support derives from comparisons of apo-vs holostructures (i.e. unliganded vs ligand bound) in which the only conformational differences occur in that region $(98,128)$. Furthermore, the terminal methyl carbon of oleate protrudes slightly from the small surface opening $(129,130)$.

One theory describing probable forces driving protein folding predicts an initial nonspecific collapse preceding the formation of organized tertiary structure. Such a collapse is nucleated by interactions between specific nonpolar amino acids that form a hydrophobic core. Searches for motifs of this kind in the intracellular LBP structures have highlighted a series of primarily nonconsecutive hydrophobic residues that are conserved between family members (3). These residues cluster to generate a hydrophobic backbone that may be partly responsible for the basic intracellular LBP fold.

Several of the intracellular LBP crystal structures have been refined sufficiently to assign coordinates not only to the expected covalent atoms of the protein and/or bound ligand but also to noncovalently held water molecules $(98,129,130)$. These crystallographically ordered waters are conserved between apo-and holo-structures of the same protein, and to some degree, between proteins. Some of them, as mentioned above, fill portions of the gap not occupied by side-chain atoms. About ten conserved waters are located within the cavity such that they form part of the ligand contact site. The conserved water and polar side-chains are present in the cavity presumably to stabilize the structure of the protein and to preserve the central ligand cavity. Bound water may present an attractive force for the acyl tail by taking on a nonpolar character in the tightly bound state.

\section{FUNCTIONAL ANALYSIS OF THE FABPs}

FABPs, as suggested by the name, generally exhibit a preference for fatty acids. More specifically, only long-chain fatty acids will bind FABPs with measurable affinity. Each protein molecule will bind and sequester within its cavity a single hydrophobic ligand. The exception to this is the liver FABP, which is capable of binding two fatty acids (121).

Affinity for fatty acids appears to be related to chain length, since 16-20 carbon fatty acids have the lowest dissociation constants. Degree of saturation may play a role: Systematic comparison of the binding properties of several FABPs established a correlation between the number of double bonds and affinity (91). For certain FABPs, such as liver FABP, affinity decreased with increasing unsaturation. However, for adipocyte LBP, no discrimination in binding between saturated and unsaturated fatty acids was noted. The effect may arise from the inherent aqueous solubility of the ligand itself, or the number of polar vs nonpolar cavity contacts with bound ligand, or possibly the degree of conformational restraint imposed upon the bound ligand by its cavity contacts.

Specificity for ligands in vitro shows some variation among FABP types (Table 2). Heart, adipocyte, intestinal, keratinocyte, brain, testis, myelin P2, and liver FABPs are all able to bind tightly to long-chain fatty acids. Adipocyte (MA Simpson, DA Bernlohr, unpublished results) and keratinocyte (55) LBPs are both able to bind oxidized lipid species such as hydroxy-and hydroperoxyeicosatetraenoic acids (HETEs and HPETEs), but their affinities for leukotrienes and prostaglandins are negligible. Ileal FABP (97) and intestinal bile acid- binding protein (28) both form high-affinity complexes with bile acids. Liver FABP, as previously mentioned, can bind either one or two long-chain fatty acids, but its ligands also include heme, steroids, acyl CoAs, oxidized/peroxidized fatty acids, leukotrienes, prostaglandins (90), and peroxisome proliferators (108). Brain FABP associates with fatty acids and acyl CoAs (76).

Besides long-chain fatty acids and other physiological lipids, many of the FABPs bind fluorescent or sulfonated analogs of fatty acids such as hexadecanesulfonate (63), 1-anilino-8-naphthalenesulfonate (1,8-ANS; 54), 12 (9anthroyloxy)oleate (12-AO; 104), 2-(9-anthroyloxy)palmitate (2-AP; 37),

Table 2 Ligand specificities and affinities for members of the FABP family

\begin{tabular}{lllll}
\hline \hline Protein & Ligand & $\mathrm{K}_{\mathrm{d}}$ & Method & Reference \\
\hline ALBP & Oleate & $56 \mathrm{nM}$ & ADIFAB & 91 \\
& Oleate & $2.4 \mu \mathrm{M}$ & Calorimetry & 64 \\
KLBP & Oleate & $248 \mathrm{nM}$ & ANS & 54 \\
HFABP & Oleate & $10 \mathrm{nM}$ & ADIFAB & 91 \\
BFABP & cis-Parinaric acid & $700 \mathrm{nM}$ & Fluorescence & 76 \\
IFABP & Oleate & $200 \mathrm{nM}$ & Calorimetry & 61,73 \\
& Oleate & $6 \mathrm{nM}$ & ADIFAB & 91 \\
IBABP & Chenodeoxycholate & $\mathrm{ND}$ & Gel filtration & 28 \\
ILBP & Oleate & $36 \mu \mathrm{M}$ & Calorimetry & 73 \\
LFABP & Oleate & $9 \mathrm{nM}$ & ADIFAB & 91 \\
& Oleate & $200 \mathrm{nM} ; 900 \mathrm{nM}^{\mathrm{b}}$ & Calorimetry & 73 \\
& Acyl CoA & $3-14 \mu \mathrm{M}$ & Lipidex & 44 \\
& $15-{ }^{3}[\mathrm{H}] \mathrm{HPETE}$ & $76 \mathrm{nM} ; 80 \mathrm{nM}^{\mathrm{b}}$ & Lipidex & 90 \\
& Prostaglandin El & $\mathrm{ND}$ & Lipidex & 90 \\
& Leukotriene C4 & $\mathrm{ND}$ & Lipidex & 90 \\
\hline
\end{tabular}

Denotes ligand binds, but affinity not determined.

${ }^{b}$ LFABP has a high- and a low-affinity binding site. 


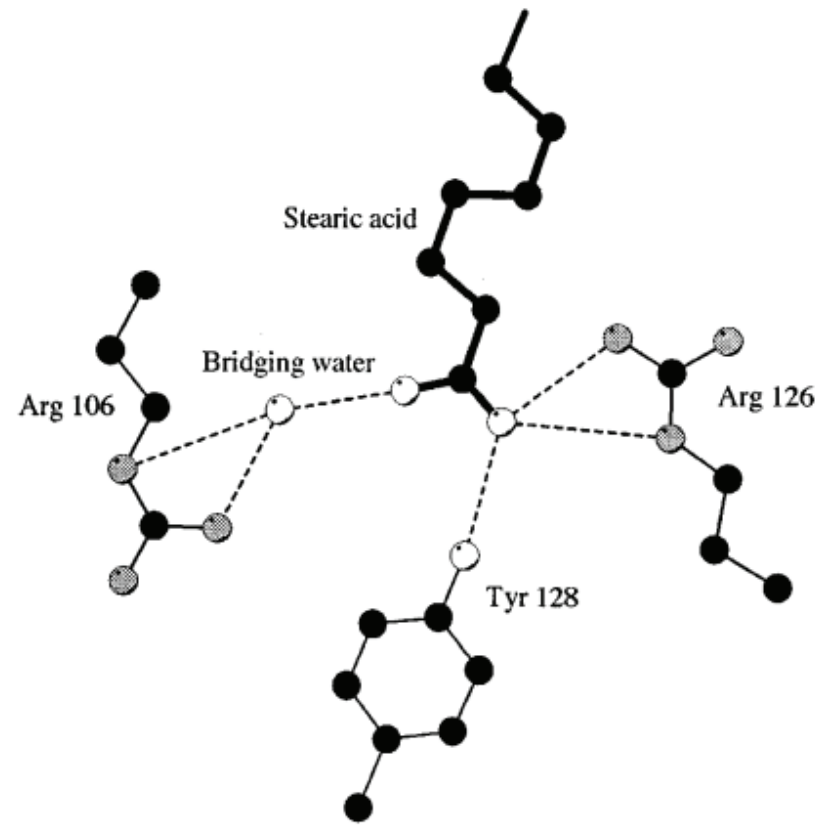

Figure 5 The FABP fatty acid-binding triad and its interactions with the carboxylate of a bound ligand. Depicted are amino acids representing adipocyte LBP residues R106, R126, and Y128, as positioned when bound to stearate. Dotted lines indicate hydrogen bonding. Open symbols represent oxygen, stippled symbols nitrogen, and filled symbols carbon atoms.

and cis-parinaric acid (cPA; 76, 104). Such ligands are particularly useful in designing assays to evaluate affinity and/or specificity of native ligands.

Numerous crystal structures have been solved in order to study the protein-lipid interactions that determine ligand affinity and specificity on a molecular level. High-resolution crystal structures are available for intestinal (99), muscle (heart; 130, 131), myelin P2 (22), and adipocyte (63, 64, 128, 129) FABPs in the absence and presence of various ligands. Examination and comparison of tertiary structures of the holoprotein, in conjunction with primary sequence information, pinpointed three conserved residues that constitute a fatty acid- binding motif. Though the precise conformation of the hydrocarbon tail varies, similar positions relative to these residues were observed for all structures. As shown in Figure 5, the bound ligand is oriented such that its negatively charged carboxylate engages in electrostatic-and hydrogen-bonding interactions with two arginines (one via a conserved, crystallographically ordered water) and a tyrosine located at the base of the cavity, opposite the portal. The tail of the lipid flattens against the wall of the cavity and either projects with a single bend toward the portal, as observed for adi- pocyte LBP binding to oleate, stearate (129), and palmitate (63), or settles into a U-shape as occurs in heart FABP (130) and adipocyte LBP with bound arachidonate (64). This triad is not preserved in liver, ileal, and intestinal FABPs, nor in cellular retinol binding proteins I and II (3). The liver and ileal proteins have broader ligand-binding specificities than most FABPs. Intestinal FABP, although specific for binding to long-chain fatty acids, retains only a single arginine from the triad motif (99). Cellular retinol binding proteins I and II utilize glutamine at the analogous position to accept a hydrogen bond from the hydroxyl head group of retinol $(22,126)$.

Nuclear magnetic resonance (NMR) studies indicated that the carboxylate of ligands bound to intestinal FABP was buried in the cavity, was non-ionizable, and that the signals normally obtained from the single conserved arginine at the base of the cavity were variable with the presence or absence of a bound ligand (18). NMR data also indicated that ileal (97) and liver (18) FABPs may bind ligands similarly to each other. Fatty acid carboxylates were ionizable, indicating solvent accessibility, and were oriented toward the surface of the binding protein. This orientation is opposite that found for intestinal FABP and most other family members.

The importance of the FABP triad was established for adipocyte LBP by mutagenizing two of its conserved residues, R126 and Y128, to leucine and phenylalanine, respectively (104). These mutations maintained essentially similar size and shape characteristics but eliminated hydrogen-bonding and charge-neutralization capabilities. The mutant protein was no longer able to bind the fluorescent fatty acid analog cis-parinaric acid, nor would it adhere to a long-chain fatty acid affinity column (MA Simpson, DA Bernlohr, unpublished results)

Mutagenesis of the intestinal FABP's conserved arginine was sufficient to disrupt fatty acid binding as assessed by NMR and titration calorimetry (48). Furthermore, conversion of this residue to glutamine, as found in the analogous position in cellular retinol binding protein II, converted intestinal FABP to a retinol-binding protein. Hence, in this family member, a specific arginine seems to influence ligand specificity.

In contrast, mutation of the analogous arginine 122 residue in liver FABP altered only slightly the protein's affinity for fatty acids (116). Instead, its affinity for acyl CoA ligands was increased. Ligands bound to liver FABP may have a greater number of nonpolar cavity contacts than ligands bound to other FABPs. Hydrophobic interactions would then contribute more significantly to binding energy than would electrostatics.

\section{Energetic Considerations}

Titration calorimetry is a technique by which stoichiometry, affinity, and heat of reaction (enthalpy) may be determined simultaneously for a binding 
interaction. With this information, the free energy and entropy of binding are then also calculable. Measurements of this kind have been conducted on adipocyte and intestinal FABPs with various ligands $(48,61,64,73)$. Dissociation constants obtained in these studies are approximately an order of magnitude larger than those assessed using fluorescent probes such as 1,8-ANS (54) and ADIFAB (acrylodan-derivatized intestinal FABP; 91). The acrylodan moiety displays a fluorescence red shift upon ligand binding, which permits quantitation of free ligand. This probe can then be used to determine binding constants for any ligand to any FABP by using a competition assay. Comparison of ADIFAB dissociation constants $\left(\mathrm{K}_{\mathrm{d}}\right)$ measured at different temperatures yields an alternative enthalpy determination via the van't Hoff equation. Despite differences in absolute dissociation constants, which probably arise because of incorrect reference heat subtractions in the older calorimetric measurements (61), the same conclusions are ultimately derived from the data and represent consistent information about forces critical to binding. In general, the affinities of fatty acids for FABPs range from 10 to $1000 \mathrm{nM}$.

Electrostatic interactions consist of charge neutralizations, hydrogen bonding, and London dispersion forces (van der Waals interactions). These interactions contribute primarily to the enthalpy of binding. Thermodynamic measurements have determined that under physiological conditions, a large negative enthalpy (i.e. an exothermic reaction) is the major driving force for the binding reaction. Large enthalpic factors arise from the polar interactions at the carboxylate, as well as the temporary induced dipoles generated between the long hydrocarbon tail and its cavity contacts. This latter factor, the van der Waals interaction, partially explains the specificity of FABPs for longchain fatty acids since there is more potential for cavity contact and, therefore, attractive forces.

A small entropic component also contributes to binding energetics. Entropy of binding results from the net balance of unfavorable entropy introduced by the protein constraining the free ligand to a rigidly bound state and the favorable release of water molecules that formerly were ordered around the lipid. Therefore, saturated ligands may exhibit a greater positive entropic effect because of their lower aqueous solubility and the greater amount of disorder that arises when they are removed from solvent.

Recent studies focusing on the kinetic aspects of ligand binding have afforded further physical knowledge about FABP ligand-binding processes. Using a more sensitive mutant of the fluorescent probe ADIFAB, Richieri et al (92) have compared on-and off-rates for adipocyte, heart, and intestinal FABPs. The adipocyte protein had the lowest rate constant for ligand binding $\left(\mathrm{k}_{\mathrm{on}}\right)$ and the highest rate of dissociation $\left(\mathrm{k}_{\mathrm{off}}\right)$ for palmitate, oleate, linoleate, linolenate, and arachidonate. Variability in affinities between proteins and different ligands resulted primarily from differences in $\mathrm{k}_{\text {off }}$. Support for involvement of the portal derives from a recent study of a variant of intestinal FABP that lacks the helix-turn-helix cap $(17,56)$. This mutant folded correctly, with some loss of stability (56), and had diminished affinity for fatty acids that was attributed primarily to an increase in ligand off-rate, while $\mathrm{k}_{\text {on }}$ remained unchanged (17). Hence, it seems that ligand binding to FABPs, traditionally considered a two-state process involving only bound or free protein, may transpire via passage through one or more intermediate states.

Kinetic studies have been used for several years to define the putative interactions that might govern transfer of ligands from FABPs to cellular membranes (110). In these experiments, a FABP (heart, adipocyte, liver, or intestinal) was loaded with a fluorescent fatty acid analog and incubated with phospholipid vesicles of defined composition. Transfer was measured as a fluorescence decrease when the fatty acid analog entered the vesicle membrane. The rate of transfer from the adipocyte, heart, and intestinal FABP depended on phospholipid composition and vesicle concentration. This observation indicates that collision of the protein with the membrane is required for lipid transfer $(37,38)$. Transfer from liver FABP occurs independently of either phospholipid composition or vesicle concentration and so is defined as diffusional (43). Global acetylation of surface lysine residues of both heart and adipocyte FABPs altered the kinetics of transfer to a diffusional mechanism and abolished the tendency of both proteins to transfer lipids more rapidly to negatively charged vesicles $(37,38)$, implicating the lysines in a pivotal role as collisional modulators. Mutants of heart FABP were constructed that neutralized the lysines at the portal and at regions remote from the portal (37). Only the neutralized portal lysines affected the transfer mechanism. The different mechanisms are particularly interesting in intestinal enterocytes, in which both liver and intestinal FABPs are found, implying that each may have a specialized function.

\section{HYPOTHESES CONCERNING FABP FUNCTIONS}

Fatty acid-binding proteins have been studied for 25 years. Despite our understanding of the biophysics and molecular genetics of fatty acid-binding proteins, questions remain surrounding their function. X-ray and NMR structures have provided a wealth of information concerning the physical factors that contribute to ligand binding affinity and specificity. Although transgenic animal studies have been informative, they have not yielded definitive conclusions concerning the physiological function and role of FABPs in lipid metabolism.

One suggested role for FABPs is sequestration of fatty acids within the cytosol. FABPs may serve as intracellular buffers for fatty acids, protecting cells from deleterious effects of excess free fatty acids by sequestering them inside the ligand cavity. This could include a more specific role in scavenging 
of potentially mutagenic reactive lipid species, particularly in the case of liver FABP and keratinocyte LBP.

FABPs are probably also involved in shuttling fatty acids within the cytosol and delivering them to specific enzyme/protein systems. They may facilitate fatty acid uptake/efflux through the plasma membrane and delivery to or export from intracellular organelles. This function could also modulate the fatty acid-sensitive acitivities of some enzymes. A related role is the possible delivery of lipids to the nucleus, where they may become cofactors for gene expression mediated by PPARs. In fact, liver FABP translocates from the cytosol to the nucleus in response to ligand binding (108).

Support for the importance of FABPs in uptake and metabolism of fatty acids derives from studies of the Pima Indians of Arizona. The Pima population has an enhanced predisposition to type II diabetes [non-insulin-dependent diabetes mellitus (NIDDM)] (115). A polymorphism in intestinal FABP segregates with the disease state, manifested by increased lipid oxidation and development of obesity and insulin resistance (2). The allele, which encodes a substitution of alanine 54 to threonine, occurs at a frequency of $30 \%$ within the Pima tribe. In vitro, A54T intestinal FABP binds fatty acids twice as tightly as the wild type. Expression of A54T intestinal FABP in the intestinal epithelial cell line, Caco2, resulted in increased fatty acid uptake and triacylglycerol secretion by these cells (1). Since elevated plasma triacylglycerols are linked to development of insulin resistance, the A54T intestinal FABP polymorphism could account for the prevalence of insulin resistance in the Pima Indians.

It is clear that nutritionally derived fatty acids are bound by intracellular fatty acid-binding proteins (122a). As more negative effects of dietary fat are revealed, understanding the structure, function, and regulation of cellular lipid carriers becomes increasingly important. Clues to the involvement of FABP function in metabolism of dietary lipids come from analysis of altered genetic states, such as that observed in the Pima Indians or mice null for $a P 2$. In the Pimas, increased lipid uptake and binding conferred by the intestinal FABP A54T polymorphism correlates with enhanced prevalence of NIDDM, while mice lacking adipocyte LBP maintain insulin sensitivity. As we learn more about the roles of different FABPs, other metabolic processes central to nutrition and human health will likely be uncovered.

\section{ACKNOWLEDGMENTS}

We would like to thank members of the Bernlohr laboratory for helpful suggestions and comments during the preparation of this review. We would also like to thank Jeramia Ory, of the Banaszak laboratory, for preparing Figure 5. This work was supported by NSF/MCB grant 9506088 and National Institutes of Health grant DK 49807 to DAB, and by National Institutes of
Health grant GM 13925 to LJB. AVH was supported by National Institutes of Health training grant 2T32 DK 07203.

\section{LITERATURE CITED}

1. Baier LJ, Bogardus C, Sacchettini JC. 1996. A polymorphism in the human intestinal fatty acid binding protein alters fatty acid transport across Caco-2 cells. J. Biol. Chem. 271:10892-96

2. Baier LJ, Sacchettini JC, Knowler WC, Eads J, Paolisso G, et al. 1995. An amino acid substitution in the human intestinal fatty acid binding protein is associated with increased fatty acid binding, increased fat oxidation and insulin resistance. J. Clin. Invest. 95:1281-87

3. Banasazk L, Winter N, Xu Z, Bernlohr DA, Cowan S, Jones TA. 1994. Lipid-binding proteins: a family of fatty acid and retinoid transport proteins. Adv. Prot. Chem. 45:89-151

4. Bass NM. 1988. The cellular fatty acid binding proteins: aspects of structure, regulation, and function. Intl. Rev. Cytol. 111:143-84

5. Bass NM. 1990. Fatty acid-binding protein expression in the liver: its regulation and relationship to the zonation of fatty acid metabolism. Mol. Cell. Biochem. 98:167-76

6. Bass NM, Manning JA, Ockner RK. 1985. Turnover and short-term regulation of fatty acid binding protein in liver. J. Biol. Chem. 260:9603-7

7. Bass NM, Manning JA, Ockner RK, Gordon JI, Seetharam S, Alpers DH. 1985. Regulation of the biosynthesis of two distinct fatty acid-binding proteins in rat liver and intestine. Influences of sex difference and of clofibrate. J. Biol. Chem. 260:1432-36

8. Becker MM, Kalinna BH, Waine GJ, McManusDP. 1994. Gene cloning, overproduction and purification of a functionally active cytoplasmic fatty acid-binding protein $(\mathrm{Sj}-\mathrm{FABPc})$ from the human blood fluke Schistosoma japonicum. Gene 148:321-51

9. Benning MM, Smith AF, Wells MA, Holden HM. 1992. Crystallization, structure determination and least-squares refinement to $1.75^{\circ} \mathrm{A}$ resolution of the fatty-acid-binding protein isolated from Manduca sexta. J. Mol. Biol. 228:208-19

10. Bernlohr DA, Doering TL, Kelly TJ Jr, Lane MD. 1984. Tissue specific expression of p422 protein, a putative lipid carrier, in mouse adipocytes. Biochem. Biophys Res. Commun. 132:850-55

11. Birkenmeier EH, Gwynn B, Howard S, Jerry J, Gordon JI, et al. 1989. Tissuespecific expression, developmental regulation, and genetic mapping of the gene encoding CCAAT/enhancer binding protein. Genes Dev. 3:1146-56

12. Birkenmeier EH, Rowe LB, Crossman MW, Gordon JI. 1994. Ileal lipid-binding protein (Illbp) gene maps to mouse chromosome 11. Mamm. Gen. 5:805-6

13. Cannon JR, Eacho PI. 1991. Interaction of LY171883 and other peroxisome proliferators with fatty-acid-binding protein isolated from rat liver. Biochem. J. 280:387-91

14. Carey JO, Neufer PD, Farrar RP, Veerkamp JH, Dohm GL. 1994. Transcriptional regulation of muscle fatty acid-binding protein. Biochem. J. 298:613-7

15. Chen JD, Evans RM. 1995. A transcriptional co-repressor that interacts with nuclear hormone receptors. Nature 377:454-57

16. Christy RJ, Yang VW, Ntambi JM, Geiman DE, Landschulz WH, et al. 1989. Differentiationinduced gene expression in 3T3-L1 preadipocytes: CCAAT/enhancer binding protein interacts with and activates the promoters of two adipocyte-specific genes. Genes Dev. 3:1323-35

17. Cistola DP, Kim K, Rogl H, Frieden C. 1996. Fatty acid interactions with a helix-less variant of intestinal fatty acid-binding protein. Biochemistry 35:7559-65

18. Cistola DP, Sachettini JC, Banaszak LJ, Walsh MT, Gordon JI. 1989. Fatty acid interactions with rat intestinal and liver fatty acid-binding proteins expressed in Escherichia coli:a ${ }^{13} \mathrm{C}$ NMR study. J. Biol. Chem. 264:2700-10

19. Clarke SD, Armstrong MK. 1989. Cellular lipid binding proteins: expression, function, and nutritional regulation. FASEB J. 3:2480-87

20. Cohn SM, Simon TC, Roth KA, Birkenmeier EH, Gordon JI. 1992. Use of transgenic mice to 
map cis-acting elements in the intestinal fatty acid binding protein gene (Fabpi) that control it cell lineage-specific and regional patterns of expression along the duodenal-colonic and cryptvillus axes of the gut epithelium. J. Cell Biol. 119:27-44

21. Cook JS, Lucas JJ, Sibley E, Bolanowski MA, Christy RJ, et al. 1988. Expression of the differentiation-induced gene for fatty acid-binding protein is activated by glucocorticoid and cAMP. Proc. Natl. Acad. Sci. USA 85:2949-53

22. Cowan SW, Newcomer ME, Jones TA. 1993. Crystallographic studies on a family of cellular lipophilic transport proteins. Refinement of P2 myelin protein and the structure determination and refinement of cellular retinol-binding protein in complex with all-trans-retinol. J. Mol. Bio 230:1225-46

23. Crossman MW, Hauft SM, Gordon JI. 1994. The mouse ileal lipid-binding protein gene: a model for studying axial patterning during gut morphogenesis. J. Cell Biol. 126:1547-64

23a. Devchand PR, Keller H, Peters JM, Vazquez M, Gonzalez FJ, Wahli W. 1996. The PPAR $\alpha$-leukotriene B4 pathway to inflammation control. Nature 384:39-43

24. Distel RJ, Robinson GS, Spiegelman BM. 1992. Fatty acid regulation of gene expression. Transcriptional and posttranscriptional mechanisms. J. Biol. Chem. 267:5937-41

25. Dreyer C, Krey G, Keller H, Givel F, Helftenbein G, Wahli W. 1992. Control of the peroxisomal beta-oxidation pathway by a novel family of nuclear hormone receptors. Cell 68:879-87

26. Feng L, Hatten ME, Heintz N. 1994. Brain lipid-binding protein (BLBP): a novel signaling system in the developing mammalian CNS. Neuron 12:895-908

27. Forman BM, Tontonoz P, Chen J, Brun RP, Spiegelman BM, Evans RM. 1995. 15-Deoxy-delta 12, 14-prostaglandin J2 is a ligand for the adipocyte determination factor PPAR gamma. Cell 83:803- 12

28. Fujita M, Fujii H, Kanda T, Sato E, Hatakeyama K, Ono T. 1995. Molecular cloning, expression, and characterization of a human intestinal 15-kDa protein. Eur. J. Biochem. 233:406-13

29. Godbout R. 1993. Identification and characterization of transcripts present at elevated levels in the undifferentiated chick retina. Exp. Eye Res. 561:95-106

30. Gong YZ, Everett ET, Schwartz DA, Norris JS, Wilson FA. 1994. Molecular cloning, tissue distribution, and expression of a 14-kDa bile acid-binding protein from rat ileal cytosol. Proc Natl. Acad. Sci. USA 91:4741-45

31. Graves RA, Tontonoz P, Ross SR, Spiegelman BM. 1991. Identification of a potent adipocytespecific enhancer: involvement of an NF-1-like factor. Genes Dev. 5:428-37

32. Graves RA, Tontonoz P, Spiegelman BM. 1992. Analysis of a tissue-specific enhancer: ARF6 regulates adipogenic gene expression. Mol. Cell. Biol. 12:1202-8

33. Green RP, Cohn SM, Sacchettini JC, Jackson KE, Gordon JI. 1992. The mouse intestinal fatty acid binding protein gene: nucleotide sequence, pattern of developmental and regional expression, and proposed structure of its protein product. DNA Cell. Biol. 11:31-41

34. Harris PK, Kletzien RF. 1994. Localization of a pioglitazone response element in the adipocyte fatty acid-binding protein gene. Mol. Pharmacol. 45:439-45

35. Hauft SM, Sweetser DA, Rotwein PS, Lajara R, Hoppe PC, et al. 1989. A transgenic mouse model that is useful for analyzing cellular and geographic differentiation of the intestine during fetal development. J. Biol. Chem. 264:8419-29

36. Hayasaka K, Himoro M, Takada G, Takahashi E, Minoshima S, Shimizu N. 1993. Structure and localization of the gene encoding human peripheral myelin protein 2 (PMP2). Genomics 18:244- 48

37. Herr FM, Aronson J, Storch J. 1996. Role of portal region lysine residues in electrostatic interactions between heart fatty acid binding protein and phospholipid membranes. Biochemistry 35 : $1296-1303$

38. Herr FM, Matarese V, Bernlohr DA, Storch J. 1995. Surface lysine residues modulate the collisional transfer of fatty acid from adipocyte fatty acid binding protein to membranes. Biochemistry 34:11840-45

39. Heuckeroth RO, Birkenmeier EH, Levin MS, Gordon JI. 1987. Analysis of the tissue-specific ex- pression, developmental regulation, and linkage relationships of a rodent gene encoding heart fatty acid binding protein. J. Biol. Chem. 262:9709-17

40. Horlein AJ, Naar AM, Heinzel T, Torchia J, Gloss B, et al. 1995. Ligand-independent repression by the thyroid hormone receptor mediated by a nuclear receptor co-repressor. Nature 377:397- 404

41. Hotamisligil GS, Budavari A, Murray D, Spiegelman BM. 1994. Reduced tyrosine kinase activity of the insulin receptor in obesity-diabetes. Central role of tumor necrosis factor-alpha. $J$. Clin. Invest. 94:1543-49

42. Hotamisligil GS, Johnson RS, Distel RJ, Ellis R, Papaioannou VE, Spiegelman BM. 1996. Uncoupling of obesity from insulin resistance through a targeted mutation in aP2, the adipocyte fatty acid binding protein. Science 274:1377-79

43. Hsu K-T, Storch J. 1996. Fatty acid transfer from liver and intestinal fatty acid-binding proteins to membranes occurs by different mechanisms. J. Biol. Chem. 271:13317-23

44. Hubbell T, Behnke WD, Woodford JK, Schroeder F. 1994. Recombinant liver fatty acid binding protein interacts with fatty acyl-coenzyme A. Biochemistry 33:3327-34

45. Hunt CR, Ro JH, Dobson DE, Min HY, Spiegelman BM. 1986. Adipocyte P2 gene: developmental expression and homology of 5'-flanking sequences among fat cell-specific genes. Proc. Natl. Acad. Sci. USA 83:3786-90

46. Issemann I, Green S. 1990. Activation of a member of the steroid hormone receptor superfamily by peroxisome proliferators. Nature 347:645-50

47. Issemann I, Prince R, Tugwood J, Green S. 1992. A role for fatty acids and liver fatty acid binding protein in peroxisome proliferation? Biochem. Soc. Trans. 20: 824-27

48. Jakoby MG, Miller KR, Toner JJ, Bauman A, Cheng L, et al. 1993. Ligand-protein electrostatic interactions govern the specificity of retinol-and fatty acid- binding proteins. Biochemistry 32:872- 78

49. Jamison RS, Newcomer ME, Ong DE. 1994. Cellular retinoid-binding proteins: Limited proteolysis reveals a conformational change upon ligand binding. Biochemistry 33:2873-79

49a. Jaworski C, Wistow G. 1996. LP2, a differentiation-associated lipid-binding protein expressed in bovine lens. Biochem. J. 320:49-54

50. Johnson PF. 1993. Identification of C/EBP basic region residues involved in DNA sequence recognition and half-site spacing preference. Mol. Cell. Biol. 13:6919-30

51. Kaikaus RM, Bass NM, Ockner RK. 1990. Functions of fatty acid binding proteins. Experientia $46: 617-30$

52. Kaikaus RM, Chan WK, Ortiz de Montellano PR, Bass NM. 1993. Mechanisms of regulation of liver fatty acid- binding protein. Mol. Cell. Biochem. 123:93-100

53. Kanda T, Odani S, Tomoi M, Matsubara Y, Ono T. 1991. Primary structure of a 15-kDa protein from rat intestinal epithelium: sequence similarity to fatty acid-binding proteins. Eur. J. Biochem. 197:759-68

54. Kane CD, Bernlohr DA. 1996. A simple assay for intracellular lipid-binding proteins using displacement of 1-anilinonaphthalene 8-sulfonic acid. Anal. Biochem. 233:197-204

55. Kane CD, Ribarik Coe N, Vanlandingham B, Krieg P, Bernlohr DA. 1996. Expression, purification, and ligand-binding analysis of recombinant keratinocyte lipid-binding protein (MAL1), an intracellular lipid-binding protein found overexpressed in neoplastic skin cells. Biochemistry 35:2894-900

56. Kim K, Cistola DP, Frieden C. 1996. Intestinal fatty acid-binding protein: the structure and stability of a helix-less variant. Biochemistry 35:7553-58

57. Kliewer SA, Forman BM, Blumberg B, Ong ES, Borgmeyer U, et al. 1994. Differential expression and activation of a family of murine peroxisome proliferator-activated receptors. Proc. Natl. Acad. Sci. USA 91:7355-59

58. Kliewer SA, Lenhard JM, Willson TM, Patel I, Morris DC, Lehmann JM. 1995. A prostaglandin J2 metabolite binds peroxisome proliferator-activated receptor gamma and promotes adipocyte differentiation. Cell 83:813-19 
59. Kliewer SA, Umesono K, Noonan DJ, Heyman RA, Evans RM. 1992. Convergence of 9-cis retinoic acid and peroxisome proliferator signalling pathways through heterodimer formation of their receptors. Nature 358:771-74

60. Krieg P, Feil S, Furstenberger G, Bowden GT. 1993. Tumor-specific overexpression of a nove keratinocyte lipid-binding protein. Identification and characterization of a cloned sequence activated during multistage carcinogenesis in mouse skin. J. Biol. Chem. 268:17362-69

61. Kurian E, Kirk WR, Prendergast FG. 1996. Affinity of fatty acid for rRat intestinal fatty acid binding protein: further examination. Biochemistry 35:3865-74

62. Kurtz A, Zimmer A, Schnutgen F, Bruning G, Spener F, Muller T. 1994. The expression pattern of a novel gene encoding brain-fatty acid binding protein correlates with neuronal and glial cell development. Development 120:2637-49

63. LaLonde JM, Bernlohr DA, Banaszak LJ. 1994. X-ray crystallographic structures of adipocyte lipid-binding protein complexed with palmitate and hexadecanesulfonic acid. Properties of cavity binding sites. Biochemistry 33:4885-95

64. LaLonde JM, Levenson MA, Roe JJ, Bernlohr DA, Banaszak LJ 1994. Adipocyte lipid-bindin protein complexed with arachidonic acid. Titration calorimetry and $\mathrm{x}$-ray crystallographic studies. J. Biol. Chem. 269:25339-47

65. Landschulz WH, Johnson PF, Adashi EY, Graves BJ, McKnight SL. 1989. Isolation of a recombinant copy of the gene encoding C/EBP. Genes Dev. 2:786-800

66. Lehmann JM, Moore LB, Smith-Oliver TA, WilkisonWO,Willson TM, Kliewer SA. 1995. An antidiabetic thiazolidinedione is a high affinity ligand for peroxisome proliferator-activated receptor gamma (PPAR gamma). J. Biol. Chem. 270:12953-56

67. Lemberger T, Saladin R, Vazquez M, Assimacopoulos F, Staels B, et al. 1996. Expression of the peroxisome proliferator-activated receptor alpha gene is stimulated by stress and follows a diurnal rhythm. J. Biol. Chem. 271:1764-69

68. Lemberger T, Staels B, Saladin R, Desvergne B, Auwerx J,WahliW. 1994. Regulation of the peroxisome proliferator-activated receptor alpha gene by glucocorticoids. J. Biol. Chem. 269:24527-30

69. Li E, Norris AW. 1996. Structure/function of cytoplasmic vitamin A-binding proteins. Annu. Rev. Nutr. 16: 205-34

70. MacDougald OA, Cornelius P, Liu R, Lane MD. 1995. Insulin regulates transcription of the CCAAT/enhancer binding protein (C/EBP) alpha, beta, and delta genes in fully-differentiated 3T3-L1 adipocytes. J. Biol. Chem. 270:647-54

71. Madsen P, Rasmussen HH, Leffers H, Honore B, Celis JE. 1992. Molecular cloning and expression of a novel keratinocyte protein psoriasis-associated fatty acid-binding protein (PA-FABP) that is highly upregulated in psoriatic skin and that shares similarity to fatty acid-binding proteins. J. Invest. Dermatol. 99:299-305

72. Medzihradszky KF, Gibson BW, Kaur S, Yu ZH, Medzihradszky D, et al. 1992. The primary structure of fatty acid-binding protein from nurse shark liver. Structural and evolutionary relationship to the mammalian fatty-acidbinding protein family. Eur. J. Biochem. 203:327-39

73. Miller KR, Cistola DP. 1993. Titration calorimetry as a binding assay for lipidbinding proteins. Mol. Cell. Biochem. 123:29-37

74. Miyata KS, McCaw SE, Patel HV, Rachubinski RA, Capone JP. 1996. The orphan nuclear hormone receptor LXR alpha interacts with the peroxisome proliferator-activated receptor and inhibits peroxisome proliferator signaling. J. Biol. Chem. 271:9189-92

75. Moser D, Tendler M, Griffiths G, Klinkert MQ. 1991. A 14-kDa Schistosoma mansoni polypeptide is homologous to a gene family of fatty acid binding proteins. J. Biol. Chem. 266:8447-54

76. Myers-Payne SC, Hubbell T, Pu LX, Schnutgen F, Borchers T, et al. 1996. Isolation and characterization of two fatty acid binding proteins from mouse brain. J. Neurochem. 66:1648-56

77. Narayanan V, Barbosa E, Reed R, Tennekoon G. 1988. Characterization of a cloned cDNAencoding rabbit myelin P2 protein. J. Biol. Chem. 263:8332-37

78. Narayanan V, Kaestner KH, Tennekoon GI. 1991. Structure of the mouse myelin P2 protein gene. J. Neurochem. 57:75-80
79. Nerlov C, Ziff EB. 1994. Three levels of functional interaction determine the activity of CCAAT/ enhancer binding protein-alpha on the serum albumin promoter. Genes Dev. 8:350-62

80. Ockner RK, Lysenko N, Manning JA, Monroe SE, Burnett DA. 1980. Sex steroid modulation of fatty acid utilization and fatty acid binding protein concentration in rat liver. J. Clin. Invest. 65:1013-23

81. Ockner RK, Manning JA, Poppenhausen RB, Ho WK. 1972. A binding protein for fatty acids in cytosol of intestinal mucosa, liver, myocardium, and other tissues. Science 177:56-58

82. Oelkers P, Dawson PA. 1995. Cloning and chromosomal localization of the human ileal lipidbinding protein. Biochim. Biophys. Acta 1257:199-202

83. Oko R, Morales CR. 1994. A novel testicular protein, with sequence similarities to a family of lipid binding proteins, is a major component of the rat sperm perinuclear theca. Dev. Biol. $166: 235-45$

84. Palmer CN, Hsu MH, Griffin HJ, Johnson EF. 1995. Novel sequence determinants in peroxisome proliferator signaling. J. Biol. Chem. 270:16114-2

85. Paulussen RJ, Geelen MJ, Beynen AC, Veerkamp JH. 1989. Immunochemical quantitation of fatty-acid-binding proteins. I. Tissue and intracellular distribution, postnatal development and influence of physiological conditions on rat heart and liver FABP. Biochim. Biophys. Acto 1001:201-9

86. Peeters RA, Veerkamp JH, Geurts van Kessel A, Kanda T, Ono T. 1991. Cloning of the cDNA encoding human skeletal-muscle fatty-acid-binding protein, its peptide sequence and chromosomal localization. Biochem. J. 276:203-7

87. Phillips M, Djian P, Green H. 1986. The nucleotide sequence of three genes participating in the adipose differentiation of 3T3 cells. J. Biol. Chem. 261:10821-27

88. [Deleted ]

89. Rauscher FJ 3d, Sambucetti LC, Curran T, Distel RJ, Spiegelman BM. 1988. Common DNA binding site for Fos protein complexes and transcription factor AP-1. Cell 52:471-80

90. Raza H, Pongubala JR, Sorof S. 1989. Specific high affinity binding of lipoxygenase metabolites of arachidonic acid by liver fatty acid binding protein. Biochem. Biophys. Res. Commun. 161:448-55

91. Richieri GV, Ogata RT, Kleinfeld AM. 1994. Equilibrium constants for the binding of fatty acids with fatty acid- binding proteins from adipocyte, intestine, heart, and liver measured with the fluorescent probe ADIFAB. J. Biol. Chem. 269:23918-30

92. Richieri GV, Ogata RT, Kleinfeld AM. 1996. Kinetics of fatty acid interactions with fatty acid binding proteins from adipocyte, heart, and intestine. J. Biol.Chem. 271:11291-300

93. Rodriguez-Perez J, Rodriguez-Medina JR, Garcia-Blanco MA, Hillyer GV. 1992. Fasciola hepatica: molecular cloning, nucleotide sequence, and expression of a gene encoding a polypeptid homologous to a Schistosoma mansoni fatty acid-binding protein. Exp. Parasitol. 74:400-7

94. Ross SR, Graves RA, Greenstein A, Platt KA, Shyu HL, et al. 1990. A fat-specific enhancer is the primary determinant of gene expression for adipocyte P2 in vivo. Proc. Natl. Acad. Sci. USA 87:9590-94

95. Rottman JN, Gordon JI. 1993. Comparison of the patterns of expression of rat intestinal fatty acid binding protein/human growth hormone fusion genes in cultured intestinal epithelial cell lines and in the gut epithelium of transgenic mice. J. Biol. Chem. 268:11994-2002

96. Sacchettini JC, Gordon JI, Banaszak LJ. 1989. Refined apoprotein structure of rat intestinal fatty acid binding protein produced in Escherichia coli. Proc. Natl. Acad. Sci. USA 86:7736-40

97. Sachettini JC, Hauft SM, Van Camp SL, Cistola DP, Gordon JI. 1990. Developmental and structural studies of an intracellular lipid binding protein expressed in the ileal epithelium. J. Biol. Chem. 265:19199-207

98. Sacchettini JC, Scapin G, Gopaul D, Gordon JI. 1992. Refinement of the Structure of Escherichia coli-derived rat intestinal fatty acid binding protein with bound oleate to $1.75-\AA$ resolution. Correlation with the structures of the apoprotein and the protein with bound palmitate.. Biol. Chem. 267:23534- 45 
99. Scapin G, Gordon JI, Sacchettini JC. 1992. Refinement of the structure of recombinant rat intestinal fatty acid- binding apoprotein at 1.2- $\AA$ resolution. J. Biol. Chem. 267:4253-69

100. Scapin G, Spadon P, Mammi M, Zanotti G, Monaco HL. 1990. Crystal structure of chicken liver basic fatty acid-binding protein at 2.7-A resolution. Molec. Cell. Biochem. 98:95-99

101. Schleicher CH, Cordoba OL, Santome JA, Dell'Angelica EC. 1995. Molecular evolution of the multigene family of intracellular lipid-binding proteins. Biochem. Molec. Biol. Int. 36:1117-25

102. [Deleted ]

103. Schoonjans K, Staels B, Auwerx J. 1996. The peroxisome proliferator activated receptors (PPARs) and their effects on lipid metabolism and adipocyte differentiation. Biochim. Biophys. Acta-Lipids Lipid Metab. 1302:93-109

104. Sha RS, Kane CD, Xu Z, Banaszak LJ, Bernlohr DA. 1993. Modulation of ligand binding affinity of the adipocyte lipid-binding protein by selective mutation: analysis in vitro and in situ. $J$. Biol. Chem. 268:7885-92

105. Siegenthaler G, Hotz R, Chatellard-Gruaz D, Didierjean L, Hellman U, Saurat JH. 1994. Purification and characterization of the human epidermal fatty acid-binding protein: localization during epidermal cell differentiation in vivo and in vitro. Biochem. J. 302:363-71

106. Simon TC, Roth KA, Gordon JI. 1993. Use of transgenic mice to map cis-acting elements in the liver fatty acid-binding protein gene $(\mathrm{Fabpl})$ that regulate its cell lineage-specific, differentiationdependent, and spatial patterns of expression in the gut epithelium and in the liver acinus. $J$. Biol. Chem. 268:18345-58

107. Smith AF, Tsuchida K, Hanneman E, Suzuki TC, Wells MA. 1992. Isolation, characterization, and cDNA sequence of two fatty acid-binding proteins from the midgut of Manduca sexta larvae. J. Biol. Chem. 267:380-84

108. Sorof S. 1994. Modulation of mitogenesis by liver fatty acid binding protein. Cancer Metastasis Rev. 13:317-36

109. Steineger HH, Sorensen HN, Tugwood JD, Skrede S, Spydevold O, Gautvik KM. 1994. Dexamethasone and insulin demonstrate marked and opposite regulation of the steady-state mRNA level of the peroxisomal proliferator-activated receptor (PPAR) in hepatic cells. Hormonal modulation of fatty-acid-induced transcription. Eur. J. Biochem. 225:967-74

110. Storch J. 1993. Diversity of fatty acid-binding protein structure and function: studies with fluorescent ligands. Mol. Cell. Biochem. 123:45-53

111. Sweetser DA, Birkenmeier EH, Hoppe PC, McKeel DW, Gordon JI. 1988. Mechanisms underlying generation of gradients in gene expression within the intestine: an analysis using transgenic mice containing fatty acid binding protein-human growth hormone fusion genes. Genes Dev. 2:1318-32

112. Sweetser DA, Birkenmeier EH, Klisak IJ, Zollman S, Sparkes RS, et al. 1987. The human and rodent intestinal fatty acid binding protein genes. A comparative analysis of their structure, expression, and linkage relationships. J. Biol. Chem. 262:16060-71

113. Sweetser DA, Hauft SM, Hoppe PC, Birkenmeier EH, Gordon JI. 1988. Transgenic mice containing intestinal fatty acid-binding protein-human growth hormone fusion genes exhibit correct regional and cell-specific expression of the reporter gene in their small intestine. Proc. Natl. Acad. Sci. USA 85:9611-15

114. Sweetser DA, Lowe JB, Gordon JI. 1986. The nucleotide sequence of the rat liver fatty acidbinding protein gene. Evidence that exon 1 encodes an oligopeptide domain shared by a family of proteins which bind hydrophobic ligands. J. Biol. Chem. 261:5553-61

115. Tataranni PA, Baier LJ, Paolisso G, Howard BV, Ravussin E. 1996. Role of lipids in development of noninsulindependent diabetes mellitus: lessons learned from Pima Indians. Lipids 31 S267-70

116. Thumser AEA, Voysey J, Wilton DC. 1996. Mutations of recombinant rat liver fatty acid-binding protein at residues 102 and 122 alter its structural integrity and affinity for physiological ligands. Biochem. J. 314:943-49

117. Tontonoz P, Hu E, Graves RA, Budavari AI, Spiegelman BM. 1994. mPPAR gamma 2: tissue- specific regulator of an adipocyte enhancer. Genes Dev 8:1224-34

118. Treuner M, Kozak CA, Gallahan D, Grosse R, Muller T. 1994. Cloning and characterization of the mouse gene encoding mammary-derived growth inhibitor/heart-fatty acid-binding protein. Gene 147:237-42

119. Tweedie S, Edwards Y. 1989. cDNA sequence for mouse heart fatty acid binding protein, HFABP. Nucleic Acids Res. 17:4374

120. Umek RM, Friedman AD, McKnight SL. 1991. CCAAT-enhancer binding protein: a component of a differentiation switch. Science 251:288-92

121. Veerkamp JH, Maatman RGHJ. 1995. Cytoplasmic fatty acid-binding proteins: their structure and genes. Prog. Lipid Res. 34:17-52

122. Vidal-Puig A, Jimenez-Linan M, Lowell BB, Hamann A, Hu E, et al 1996. Regulation of PPAR gamma gene expression by nutrition and obesity in rodents. J. Clin. Invest. 97:2553-61

122a. Waggoner DW, Bernlohr DA. 1990. In situ labeling of the adipocyte lipid binding protein with 3-[ ${ }^{125}$ I]iodo-4-azido-Nhexadecylsalicylamide. Evidence for a role of fatty acid binding proteins in lipid uptake. J. Biol. Chem. 265:11417-20

123. Wedel A, Ziegler-Heitbrock HW. 1995. The C/EBP family of transcription factors. Immunobiology 193:171-85

124. Wen Y, Li GW, Chen P, Wong E, Bekhor I. 1995. Lens epithelial cell mRNA. II. Expression of a mRNA encoding a lipid-binding protein in rat lens epithelial cells. Gene 158:269-74

125. Williams SC, Cantwell CA, Johnson PF. 1991. A family of C/EBP-related proteins capable of forming covalently linked leucine zipper dimers in vitro. Genes Dev. 5:1553-67

125a. Wilson R, Ainscough R, Anderson K, Baynes C, Berks M, et al. 1996. 2. 2 Mb of contiguous nucleotide sequence from chromosome III of C. elegans. Nature 368:32-38

126. Winter NS, Bratt JM, Banaszak LJ. 1993. Crystal structures of holo and apo-cellular retinolbinding protein II. J. Mol. Biol. 230:1247-59

127. Wu ZD, Bucher NLR, Farmer SR. 1996. Induction of peroxisome proliferatoractivated receptor gamma during the conversion of $3 \mathrm{~T} 3$ fibroblasts into adipocytes is mediated by $\mathrm{C} / \mathrm{EBP}-$ beta, $\mathrm{C}$ / EBP-delta, and glucocorticoids. Mol. Cell. Biol. 16:4128-36

128. Xu Z, Bernlohr DA, Banaszak LJ. 1992. Crystal structure of recombinant murine adipocyte lipid-binding protein. Biochemistry 31:3484-92

129. Xu Z, Bernlohr DA, Banaszak LJ. 1993. The adipocyte lipid-binding protein at 1.6-A. Crysta structures of the apoprotein and with bound saturated and unsaturated fatty acids. J. Biol. Chem. 268:7874-84

130. Young ACM, Scapin G, Kromminga A, Patel SB, Veerkamp JH, Sacchettini JC. 1994. Structural studies on human muscle fatty acid binding protein at $1.4 \AA$ resolution: binding interactions with three C18 fatty acids. Structure 2:523-34

131. Zanotti G, Scapin G, Spadon P, Veerkamp JH, Sacchettini JC. 1992. Three-dimensional structure of recombinant human muscle fatty acid-binding protein. J. Biol. Chem. 267:18541-50

132. Zschiesche W, Kleine AH, Spitzer E, Veerkamp JH, Glatz JF. 1995. Histochemical localization of heart-type fatty-acid binding protein in human and murine tissues. Histochem. Cell Biol. 103:147-56

133. Zhu Y, Alvares K, Huang Q, Rao MS, Reddy JK. 1993. Cloning of a new member of the peroxisome proliferatoractivated receptor gene family from mouse liver. J. Biol. Chem. 268:26817-20 